\title{
ASYMPTOTIC EXPANSION AND BOUNDS FOR COMPLETE ELLIPTIC INTEGRALS
}

\author{
Miao-Kun Wang, Yu-Ming Chu, Yong-Min Li And Wen Zhang
}

Abstract. In the article, we present several new bounds for the the complete elliptic integrals $\mathscr{K}(r)=\int_{0}^{\pi / 2}\left(1-r^{2} \sin ^{2} \theta\right)^{-1 / 2} d \theta$ and $\mathscr{E}(r)=\int_{0}^{\pi / 2}\left(1-r^{2} \sin ^{2} \theta\right)^{1 / 2} d \theta$, and find an asymptotic expansion for $\mathscr{K}(r)$ as $r \rightarrow 1$, which are the refinements and improvements of the previously well-known results.

Mathematics subject classification (2010): 33E05, 26E60.

Keywords and phrases: Asymptotic expansion, complete elliptic integrals, arithmetic-geometric mean, infinite series, bound.

\section{REFERENCES}

[1] I. Abbas Baloch, Y.-M. Chu, Petrović-type inequalities for harmonic $h$-convex functions, J. Funct. Spaces 2020 (2020), Article ID 3075390, 7 pages.

[2] M. Adil Khan, S. Begum, Y. Khurshid, Y.-M. Chu, Ostrowski type inequalities involving conformable fractional integrals, J. Inequal. Appl. 2018 (2018), Article 70, 14 pages.

[3] M. Adil Khan, Y.-M. Chu, A. KAshuri, R. Liko, G. Ali, Conformable fractional integrals versions of Hermite-Hadamard inequalities and their generalizations, J. Funct. Spaces 2018 (2018), Article ID 6928130, 9 pages.

[4] M. Adil Khan, Y.-M. Chu, T. U. Khan, J. Khan, Some new inequalities of Hermite-Hadamard type for s-convex functions with applications, Open Math. 15, 1 (2017), 1414-1430.

[5] M. Adil Khan, M. Hanif, Z. A. Khan, K. Ahmad, Y.-M. Chu, Association of Jensen's inequality for s-convex function with Csiszár divergence, J. Inequal. Appl. 2019 (2019), Article 162, 14 pages.

[6] M. Adil Khan, A. Iqbal, M. Suleman, Y.-M. Chu, Hermite-Hadamard type inequalities for fractional integrals via Green's function, J. Inequal. Appl. 2018 (2018), Article 161, 15 pages.

[7] M. Adil Khan, Y. Khurshid, T.-S. Du, Y.-M. CHU, Generalization of Hermite-Hadamard type inequalities via conformable fractional integrals, J. Funct. Spaces 2018 (2018), Article ID 5357463, 12 pages.

[8] M. Adil Khan, N. Mohammad, E. R. Nwaeze, Y.-M. Chu, Quantum Hermite-Hadamard inequality by means of a Green function, Adv. Difference Equ. 2020 (2020), Article 99, 20 pages.

[9] M. Adil Khan, S.-H. Wu, H. Ullah, Y.-M. Chu, Discrete majorization type inequalities for convex functions on rectangles, J. Inequal. Appl. 2019 (2019), Article 16, 18 pages.

[10] M. Adil Khan, S. Zaheer Ullah, Y.-M. Chu, The concept of coordinate strongly convex functions and related inequalities, Rev. R. Acad. Cienc. Exactas Fís. Nat. Ser. A Mat. RACSAM 113, 3 (2019), 2235-2251.

[11] H. AlZER, S.-L. QIU, Monotonicity theorems and inequalities for the complete elliptic integrals, J. Comput. Appl. Math. 172, 2 (2004), 289-312.

[12] G. D. Anderson, M. K. VAmanamurthy, M. Vuorinen, Functional inequalities for hypergeometric functions and complete elliptic integrals, SIAM J. Math. Anal. 23, 2 (1992), 512-524.

[13] G. D. Anderson, M. K. Vamanamurthy, M. Vuorinen, Conformal Invariants, Inequalities, and Quasiconformal Maps, John Wiley \& Sons, New York, 1997.

[14] R. W. BARnARD, K. PEARCE, K. C. RiChARDS, An inequality involving the generalized hypergeometric function and the arc length of an ellipse, SIAM J. Math. Anal. 31, 3 (2000), 693-699. 
[15] R. W. Barnard, K. Pearce, K. C. Richards, A monotonicity property involving ${ }_{3} F_{2}$ and comparisons of the classical approximations of elliptical arc length, SIAM J. Math. Anal. 32, 2 (2000), 403-419.

[16] Y.-M. Chu, M. Adil Khan, T. Ali, S. S. Dragomir, Inequalities for $\alpha$-fractional differentiable functions, J. Inequal. Appl. 2017 (2017), Article 93, 12 pages.

[17] Y.-M. Chu, B.-Y. Long, Sharp inequalities between means, Math. Inequal. Appl. 14, 3 (2011), $647-655$.

[18] Y.-M. CHU, Y.-F. QIU, M.-K. WANG, Hölder mean inequalities for the complete elliptic integrals, Integral Transforms Spec. Funct. 23, 7 (2012), 521-527.

[19] Y.-M. CHU, M.-K. WANG, Inequalities between arithmetic-geometric, Gini, and Toader means, Abstr. Appl. Anal. 2012 (2012), Article ID 830585, 11 pages.

[20] Y.-M. ChU, M.-K. WANG, Optimal Lehmer mean bounds for the Toader mean, Results Math. 61, 3-4 (2012), 223-229.

[21] Y.-M. ChU, M.-K. WANG, Y.-P. Jiang, S.-L. QIU, Concavity of the complete elliptic integrals of the second kind with respect to Hölder means, J. Math. Anal. Appl. 395, 2 (2012), 637-642.

[22] Y.-M. CHU, M.-K. WANG, S.-L. QIU, Optimal combinations bounds of root-square and arithmetic means for Toader mean, Proc. Indian Acad. Sci. Math. Sci. 122, 1 (2012), 41-51.

[23] Y.-M. ChU, M.-K. WANG, S.-L. QIU, Y.-P. JIANG, Bounds for complete elliptic integrals of the second kind with applications, Comput. Math. Appl. 63, 7 (2012), 1177-1184.

[24] Y.-M. ChU, G.-D. WANG, X.-H. Zhang, The Schur multiplicative and harmonic convexities of the complete symmetric function, Math. Nachr. 284, 5-6 (2011), 653-663.

[25] Y.-M. ChU, W.-F. XIA, X.-H. ZHANG, The Schur concavity, Schur multiplicative and harmonic convexities of the second dual form of the Hamy symmetric function with applications, J. Multivariate Anal. 105 (2012), 412-421.

[26] G.-J. HAI, T.-H. ZHAO, Monotonicity properties and bounds involving the two-parameter generalized Grötzsch ring function, J. Inequal. Appl. 2020 (2020), Article 66, 17 pages.

[27] X.-H. He, W.-M. Qian, H.-Z. XU, Y.-M. ChU, Sharp power mean bounds for two Sándor-Yang means, Rev. R. Acad. Cienc. Exactas Fís. Nat. Ser. A Mat. RACSAM 113, 3 (2019), 2627-2638.

[28] X.-M. HU, J.-F. TIAN, Y.-M. ChU, Y.-X. LU, On Cauchy-Schwarz inequality for N-tuple diamondalpha integral, J. Inequal. Appl. 2020 (2020), Article 8, 15 pages.

[29] T.-R. HuAnG, B.-W. HAN, X.-Y. MA, Y.-M. ChU, Optimal bounds for the generalized EulerMascheroni constant, J. Inequal. Appl. 2018 (2018), Article 118, 9 pages.

[30] T.-R. HuAng, S.-Y. TAN, X.-Y. MA, Y.-M. ChU, Monotonicity properties and bounds for the complete p-elliptic integrals, J. Inequal. Appl. 2018 (2018), Article 239, 11 pages.

[31] A. IQbal, M. Adil Khan, S. Ullah, Y.-M. ChU, Some new Hermite-Hadamard-type inequalities associated with conformable fractional integrals and their applications, J. Funct. Spaces 2020 (2020), Article ID 9845407, 18 pages.

[32] S. Khan, M. Adil Khan, Y.-M. Chu, Converses of the Jensen inequality derived from the Green functions with applications in information theory, Math. Methods Appl. Sci. 43, 5 (2020), 2577-2587.

[33] Y. Khurshid, M. Adil Khan, Y.-M. ChU, Conformable integral inequalities of the HermiteHadamard type in terms of GG-and GA-convexities, J. Funct. Spaces 2019 (2019), Article ID 6926107, 8 pages.

[34] Y. Khurshid, M. Adil Khan, Y.-M. Chu, Z. A. Khan, Hermite-Hadamard-Fejér inequalities for conformable fractional integrals via preinvex functions, J. Funct. Spaces 2019 (2019), Article ID 3146210, 9 pages.

[35] M. A. Latif, S. Rashid, S. S. Dragomir, Y.-M. Chu, Hermite-Hadamard type inequalities for co-ordinated convex and qausi-convex functions and their applications, J. Inequal. Appl. 2019 (2019), Article 317, 33 pages.

[36] W.-M. QIAN AND Y.-M. ChU, Sharp bounds for a special quasi-arithmetic mean in terms of arithmetic and geometric means with two parameters, J. Inequal. Appl. 2017 (2017), Article 274, 10 pages.

[37] W.-M. QIAn, Z.-Y. HE, Y.-M. ChU, Approximation for the complete elliptic integral of the first kind, Rev. R. Acad. Cienc. Exactas Fís. Nat. Ser. A Mat. RACSAM 114, 2 (2020), Article 57, 12 pages. Available online at https://doi.org/10.1007/s13398-020-00784-9.

[38] W.-M. Qian, Z.-Y. HE, H.-W. Zhang, Y.-M. ChU, Sharp bounds for Neuman means in terms of two-parameter contraharmonic and arithmetic mean, J. Inequal. Appl. 2019 (2019), Articel 168, 13 pages. 
[39] W.-M. QIAn, H.-Z. XU, Y.-M. CHU, Improvements of bounds for the Sándor-Yang means, J. Inequal. Appl. 2019 (2019), Article 73, 8 pages.

[40] W.-M. Qian, Y.-Y. YAng, H.-W. Zhang, Y.-M. ChU, Optimal two-parameter geometric and arithmetic mean bounds for the Sándor-Yang mean, J. Inequal. Appl. 2019 (2019), Article 287, 12 pages.

[41] W.-M. QIAN, X.-H. ZHANG, Y.-M. CHU, Sharp bounds for the Toader-Qi mean in terms of harmonic and geometric means, J. Math. Inequal. 11, 1 (2017), 121-127.

[42] W.-M. QIAN, W. ZHANG, Y.-M. CHU, Bounding the convex combination of arithmetic and integral means in terms of one-parameter harmonic and geometric means, Miskolc Math. Notes 20, 2 (2019), 1157-1166.

[43] S.-L. QIU, X.-Y. MA, Y.-M. CHU, Sharp Landen transformation inequalities for hypergeometric functions, with applications, J. Math. Anal. Appl. 474, 2 (2019), 1306-1337.

[44] S.-L. QIU, M. VUORINEN, Duplication inequalities for the ratios of hypergeometric functions, Forum Math. 12, 1 (2000), 109-133.

[45] Y.-F. QiU, M.-K. WAng, Y.-M. ChU, G.-D. WAng, Two sharp inequalities for Lehmer mean, identric mean and logarithmic mean, J. Math. Inequal. 5, 3 (2011), 301-306.

[46] S. Rafeeq, H. Kalsoom, S. Hussain, S. Rashid, Y.-M. Chu, Delay dynamic double integral inequalities on time scales with applications, Adv. Difference Equ. 2020 (2020), Article 40, 32 pages.

[47] S. Rashid, R. Ashraf, M. A. Noor, K. I. Noor, Y.-M. CHU, New weighted generalizations for differentiable exponentially convex mapping with application, AIMS Math. 5, 4 (2020), 3525-3546.

[48] S. RASHID, F. JARAD, Y.-M. CHU, A note on reverse Minkowski inequality via generalized proportional fractional integral operator with respect to another function, Math. Probl. Eng. 2020 (2020), Article ID 7630260, 12 pages.

[49] S. RAShid, F. JARAD, H. KAlsoom AND Y.-M. CHU, On Pólya-Szegö and Ćebyšev type inequalities via generalized $k$-fractional integrals, Adv. Difference Equ. 2020 (2020), Article 125, 18 pages.

[50] S. Rashid, M. A. Noor, K. I. Noor, Y.-M. CHU, Ostrowski type inequalities in the sense of generalized $\mathscr{K}$-fractional integral operator for exponentially convex functions, AIMS Math. 5, 3 (2020), 2629-2645.

[51] J. SÁndor, On certain inequalities for means, J. Math. Anal. Appl. 189, 2 (1995), 602-606.

[52] Y.-Q. Song, M. Adil Khan, S. Zaheer Ullah, Y.-M. Chu, Integral inequalities involving strongly convex functions, J. Funct. Spaces 2018 (2018), Article ID 6595921, 8 pages.

[53] GH. TOAdER, Some mean values related to the arithmetic-geometric mean, J. Math. Anal. Appl. 218, 2 (1998), 358-368.

[54] M. VuORINEN, Hypergeometric functions in geometric function theory, in: Special Functions and Differential Equations (Madras, 1997), 119-126, Allied Publ., New Delhi, 1998.

[55] M.-K. WANG, Y.-M. CHU, Refinements of transformation inequalities for zero-balanced hypergeometric functions, Acta Math. Sci. 37B, 3 (2017), 607-622.

[56] M.-K. WANG, Y.-M. CHU, Landen inequalities for a class of hypergeometric functions with applications, Math. Inequal. Appl. 21, 2 (2018), 521-537.

[57] M.-K. Wang, H.-H. CHU, Y.-M. CHU, Precise bounds for the weighted Hölder mean of the complete p-elliptic integrals, J. Math. Anal. Appl. 480, 2 (2019), Article ID 123388, 9 pages, Available online at https://doi.org/10.1016/j.jmaa.2019.123388.

[58] M.-K. WANG, Y.-M. CHU, Y.-P. JIANG, Ramanujan's cubic transformation inequalities for zerobalanced hypergeometric functions, Rocky Mountain J. Math. 46, 2 (2016), 679-691.

[59] M.-K. WANG, Y.-M. CHU, S.-L. QIU, Y.-P. JiAnG, Convexity of the complete elliptic integrals of the first kind with respect to Hölder means, J. Math. Anal. Appl. 388, 2 (2012), 1141-1146.

[60] M.-K. WAng, Y.-M. CHU, S.-L. QIU, Y.-P. JiAng, Bounds for the perimeter of an ellipse, J. Approx. Theory 164, 7 (2012), 928-937.

[61] M.-K. WAng, Y.-M. CHU, Y.-F. QIU, S.-L. QIU, An optimal power mean inequality for the complete elliptic integrals, Appl. Math. Lett. 24, 6 (2011), 887-890.

[62] M.-K. WANG, Y.-M. CHU, W. ZHANG, Monotonicity and inequalities involving zero-balanced hypergeometric function, Math. Inequal. Appl. 22, 2 (2019), 601-617.

[63] M.-K. Wang, Y.-M. Chu, W. Zhang, Precise estimates for the solution of Ramanujan's generalized modular equation, Ramanujan J. 49, 3 (2019), 653-668.

[64] M.-K. WANG, Z.-Y. HE, Y.-M. CHU, Sharp power mean inequalities for the generalized elliptic integral of the first kind, Comput. Methods Funct. Theory 20, 1 (2020), 111-124. 
[65] M.-K. Wang, M.-Y. Hong, Y.-F. XU, Z.-H. Shen, Y.-M. Chu, Inequalities for generalized trigonometric and hyperbolic functions with one parameter, J. Math. Inequal. 14, 1 (2020), 1-21.

[66] M.-K. WANG, Y.-M. LI, Y.-M. CHU, Inequalities and infinite product formula for Ramanujan generalized modular equation function, Ramanujan J. 46, 1 (2018), 189-200.

[67] B. WANG, C.-L. LUO, S.-H. LI, Y.-M. CHU, Sharp one-parameter geometric and quadratic means bounds for the Sándor-Yang means, Rev. R. Acad. Cienc. Exactas Fís. Nat. Ser. A Mat. RACSAM 114, 1 (2020), Article 7, 10 pages, Available online at https://doi.org/10.1007/s13398-019-00734-0.

[68] J.-L. WANG, W.-M. QIAn, Z.-Y. He, Y.-M. Chu, On approximating the Toader mean by other bivariate means, J. Funct. Spaces 2019 (2019), Article ID 6082413, 7 pages.

[69] M.-K. WANG, S.-L. QIU, Y.-M. CHU, Infinite series formula for Hübner upper bound function with applications to Hersch-Pfluger distortion function, Math. Inequal. Appl. 21, 3 (2018), 629-648.

[70] M.-K. WAng, S.-L. QIU, Y.-M. ChU, Y.-P. JiAng, Generalized Hersch-Pfluger distortion function and complete elliptic integrals, J. Math. Anal. Appl. 385, 1 (2012), 221-229.

[71] M.-K. WANG, Z.-K. WANG, Y.-M. CHU, An optimal double inequality between geometric and identric means, Appl. Math. Lett. 25, 3 (2012), 471-475.

[72] G.-D. WANG, X.-H. Zhang, Y.-M. CHU, A power mean inequality for the Grötzsch ring function, Math. Inequal. Appl. 14, 4 (2011), 833-837.

[73] G.-D. WANG, X.-H. ZhANG, Y.-M. ChU, A power mean inequality involving the complete elliptic integrals, Rocky Mountain J. Math. 44, 5 (2014), 1661-1667.

[74] M.-K. WANG, W. ZhANG, Y.-M. ChU, Monotonicity, convexity and inequalities involving the generalized elliptic integrals, Acta Math. Sci. 39B, 5 (2019), 1440-1450.

[75] S.-H. WU, Y.-M. CHU, Schur m-power convexity of generalized geometric Bonferroni mean involving three parameters, J. Inequal. Appl. 2019 (2019), Article 57, 11 pages.

[76] W.-F. XIA, Y.-M. CHU, The Schur convexity of Gini mean values in the sense of harmonic mean, Acta Math. Sci. 31B, 3 (2011), 1103-1112.

[77] W.-F. XiA, W. Janous, Y.-M. CHU, The optimal convex combination bounds of arithmetic and harmonic means in terms of power mean, J. Math. Inequal. 6, 2 (2012), 241-248.

[78] W.-F. XIA, Y.-M. Li, Y.-M. ChU, S.-Y. XU, W.-M. Chen, Z.-Q. ZHANG, Observer-based mixed passive and $H_{\infty}$ control for uncertain Markovian jump systems with time delays using quantized measurements, Nonlinear Anal. Hybrid Syst. 31 (2019), 233-246.

[79] W.-F. XiA, S.-Y. XU, J.-W. Luo, Z.-Q. Zhang, Y.-M. Chu, Reliable filter design for discretetime neural networks with Markovian jumping parameters and time-varying delay, J. Franklin Inst. 357, 5 (2020), 2892-2915.

[80] H.-Z.XU, Y.-M. CHU, W.-M. QIAN, Sharp bounds for the Sándor-Yang means in terms of arithmetic and contra-harmonic means, J. Inequal. Appl. 2018 (2018), Article 127, 13 pages.

[81] Z.-H. YANG, Y.-M. CHU, A monotonicity property involving the generalized elliptic integral of the first kind, Math. Inequal. Appl. 20, 3 (2017), 729-735.

[82] Z.-H. YANG, Y.-M. CHU, W. ZHANG, High accuracy asymptotic bounds for the complete elliptic integral of the second kind, Appl. Math. Comput. 348 (2019), 552-564.

[83] Z.-H. YANG, W.-M. QIAN, Y.-M. CHU, Monotonicity properties and bounds involving the complete elliptic integrals of the first kind, Math. Inequal. Appl. 21, 4 (2018), 1185-1199.

[84] Z.-H. YAng, W.-M. Qian, Y.-M. ChU, W. Zhang, Monotonicity rule for the quotient of two functions and its application, J. Inequal. Appl. 2017 (2017), Article 106, 13 pages.

[85] Z.-H. YANG, W.-M. QIAN, Y.-M. ChU, W. ZhaNG, On rational bounds for the gamma function, J. Inequal. Appl. 2017 (2017), Article 210, 17 pages.

[86] Z.-H. YANG, W.-M. QIAN, Y.-M. ChU, W. ZHANG, On approximating the error function, Math. Inequal. Appl. 21, 2 (2018), 469-479.

[87] Z.-H. YANG, W.-M. QIAN, Y.-M. ChU, W. ZhanG, On approximating the arithmetic-geometric mean and complete elliptic integral of the first kind, J. Math. Anal. Appl. 462, 2 (2018), 1714-1726.

[88] Z.-H. YANG, W.-M. QIAN, W. ZhANG, Y.-M. CHU, Notes on the complete elliptic integral of the first kind, Math. Inequal. Appl. 23, 1 (2020), 77-93.

[89] Z.-H. YANG, W. ZHANG, Y.-M. ChU, Sharp Gautschi inequality for parameter $0<p<1$ with applications, Math. Inequal. Appl. 20, 4 (2017), 1107-1120.

[90] S. Zaheer Ullah, M. Adil Khan, Y.-M. ChU, Majorization theorems for strongly convex functions, J. Inequal. Appl. 2019 (2019), Article 58, 13 pages. 
[91] S. Zaheer Ullah, M. Adil Khan, Y.-M. Chu, A note on generalized convex functions, J. Inequal. Appl. 2019 (2019), Article 291, 10 pages.

[92] S. Zaheer Ullah, M. Adil Khan, Z. A. Khan, Y.-M. Chu, Integral majorization type inequalities for the functions in the sense of strong convexity, J. Funct. Spaces 2019 (2019), Article ID 9487823, 11 pages.

[93] T.-H. ZHAO, Y.-M. CHU, H. WANG, Logarithmically complete monotonicity properties relating to the gamma function, Abstr. Appl. Anal. 2011 (2011), Article ID 896483, 13 pages.

[94] T.-H. ZHAO, L. SHI, Y.-M. CHU, Convexity and concavity of the modified Bessel functions of the first kind with respect to Hölder means, Rev. R. Acad. Cienc. Exactas Fís. Nat. Ser. A Mat. RACSAM 114, 2 (2020), Article 96, 14 pages, Available online at https://doi.org/10.1007/s13398-020-00825-3.

[95] T.-H. ZhaO, M.-K. WANG, W. ZHANG, Y.-M. CHU, Quadratic transformation inequalities for Gaussian hypergeometric function, J. Inequal. Appl. 2018 (2018), Article 251, 15 pages.

[96] T.-H.ZHAO, B.-C. ZhoU, M.-K. WANG, Y.-M. CHU, On approximating the quasi-arithmetic mean, J. Inequal. Appl. 2019 (2019), Article 42, 12 pages. 